October is also the hunting season. While deer hunting does not usually begin until about October 15, the woods are open earlier for such game as ducks, woodcock, pheasant and grouse.

So come to Nova Scotia for your meeting-and bring along the family for one of the most pleasant vacations they will ever have.

GaIL M. NobUaRY

\title{
NEWFOUNDLAND
}

Several important meetings held during the reporting quarter are of particular interest to Section members. The foremost of these was the Annual Section Meeting which took place in St. John's on December 4 and 5.

A very interesting and informative program was prepared for the 60 members and guests including a number of forestry students from Memorial University who attended one of our meetings for the first time.

The program consisted of a number of panel discussions and technical papers dealing with the Relation of Forestry to Other Resources, the Balsam Woolly Aphid problem, the Place of Economic Research in Forestry, and Modern Logging Methods.

On the recreational side delegates were tendered a reception and dinner by the host for the meeting, the government of the Province of Nfld. as well as similar activities given by industrial concerns whose business involves them in some forestry field.

A field trip to Newfoundland Fibreply Ltd. and Nfld. Hardwoods Ltd. proved very interesting and lent balance to the meeting.

At the Annual Meeting of the Nfld. Forest Protection Association the Province's most serious forest insect pest the balsam woolly aphid came in for considerable discussion and was mentioned in all reports presented at the meeting.

The infestation which now covers some 3500 square miles and, so we have been told, will undoubtedly spread throughout the province in the next 20 years has aroused considerable concern to all those who have an interest in the welfare of our forest resources. The N.F.P.A. has forwarded a Brief to the Minister of Forestry requesting an increase in all activities which may lead to control of the infestation and to keep those concerned better informed of its rate of spread and the long term effect the insect may have on the productivity of balsam fir sites in Nfld.

As a direct result of the Brief a meeting was held in mid-February between representatives of the paper industries and the Province with senior officers of the Dept. of Forestry at Ottawa to discuss all aspects of the problem and to work out some program for increasing action designed to help reduce the infestation to tolerable levels.

While it is probably not generally appreciated by all of our mainland associates we in Nfld. feel, and have been told by experts, that the aphid is more serious to Nfld. than the budworm was in New Brunswick. Ample evidence of this can be seen in Western Nfld., we regret to say.

W. A. Dickson 


\section{Nova Scotia}

Spartan Air Services Limited of Ottawa has been awarded a contract for forest inventory work in Southwestern Nova Scotia. The area covers approximately 250,000 acres.

John Zimmerman, a recent Forestry-graduate from Sweden, has been working with Nova Scotia Pulp Limited for the past seven months. This work has been part of Jahn's post-graduate visit to Canada to view forestry conditions and he plans to visit other parts of Canada as well as the U.S.A.

This can be considered to be an attempt to develop an exchange program between Swedish and Canadian Foresters.

All Committees of this Section of the C.I.F. are busy on the arrangements for the National Meeting next October. Committee Chairmen and the Council met with R.S. Jobnson, General Chairman, in Halifax on January 11th, and a further meeting will be held March 1st.

On January 7th, 1963 Nova Scotia Pulp began their "purchase-by-weight" program for all softwood and hardwood pulpwood. All wood, both from the Company's leased holdings and from private owners, is presently being brought in on a "per ton" basis.

A number of the Section members are involved in a series of thirteen television programs from Sydney which began in January. These programs deal with the various aspects of forestry in relation to Woodlot Management.

Nova Scotia Foresters retained the Maritime Foresters Curling Trophy by defeating the New Brunswick Foresters in a close match on February 23.

M. J. MacDonald

\section{MARITIME}

A Council Meeting of the Section was held January 28, 1963. Preliminary plans were made for the 1963 winter meeting to be held March 29. The meeting will include the presentation of Forestry Rings to graduating foresters of the University of New Brunswick Faculty of Forestry. The theme of the meeting will be "The Respective Roles of the Canadian Institute of Forestry, the Canadian Forestry Association and Registered Professional Foresters' Associations".

Discussion on the form and content of the C.I.F. Policy Statement was deferred until a later meeting.

The Minister of Lands and Mines for New Brunswick, Hon. H. Graham Crocker appointed R L Bishop to the Permanent Advisory Council on Resources Development.

Dr. Grant Davidson has been promoted to Associate Co-ordinator of Forest Insect and Disease Research at the Headquarters of the Forest Entomology and Pathology Branch of the Department of Forestry in Ottawa.

Dr. R. J. Bouchier succeeds Dr. Davidson in charge of Forest Pathology Investigation at the Forest Entomology and Pathology Laboratory in Fredericton.

Dr. Frank Morris was awarded the Entomological Society of Canada Gold medal, 1962, for outstanding achievements in Canadian entomology.

W. G. Paterson, a graduate of the University of New Brunswick in Civil Engineering, Class of '59, is a member of the Forestry Faculty teaching Soil 
mechanics, Hydraulics and Hydrology and Strength of Materials. This is the first time that a Civil Engineer has been a member of the Forestry Faculty. The courses provide some specialization and opportunities for forestry graduates to continue with post-graduate studies in these fields, particularly as they apply to logging.

Mr. D. W. MacLean of Ottawa was appointed Senior Research Officer of the Maritimes District, Forest Research Branch, Department of Forestry in September 1962. He replaces Mr. G. C. Cunningham who died July 1, 1962. Mr. MacLean was born in New Brunswick and obtained his degree in Forestry from the University of New Brunswick in 1941. After short periods of employment with the Department of Transport and the New Brunswick International Paper Company, Don joined the Forest Research Branch at Ottawa in 1944. He worked for many years in the field of management research in the boreal forest of northern Ontario.

Mr. E. B. Peterson has been recently appointed to the staff of the Forest Research Branch. Mr. Peterson graduated as the C.I.F. gold medalist from the University of British Columbia in 1958. He has since obtained the Master's degree from Yale University and has completed work towards his doctorate degree. His work with the Department of Forestry will be mainly in the field of silvics.

JOHN P. FraNCIS

\section{SUMMARY OF RETURNS OF MARITIME SECTION QUESTIONNAIRE ON THE FORESTRY CHRONICLE ${ }^{1}$}

(Mark the appropriate box)

(5)

Three most interesting items

Subject outside interests

of average F.C. reader

More emphasis on this type of material

I have not read this article

I have read this article

CONTENTS (Sept., 1962)

Editorial

Three Alternatives in Forest Taxation

Observations on the Formation

of Protection Wood

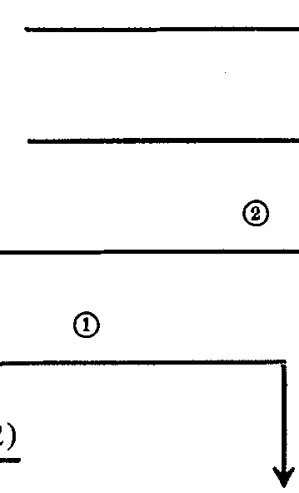

(2)
(3)

(4) 
Marketing Problems and Promotion in the Sale of Products from

Small Woodlots

Seed Moisture Content During

Stratification and Secondary

Storage of Douglas Fir

The Development of a Power

Increment Borer

The Storage of Planting Stock

in the Field

Climat estival et deperissement

du Bouleau a Papier

Tree Sway Period - A

Possible New Parameter for Crown Classification and Stand

Competition

Twenty Years Growth of

Debudded Red Pine

Breeding for Disease Resistance

in Forest Trees

Acti-Dione and Natural Bark

Extractives in the Control

of Hypoxylon Canker of Poplar ....

News and Notes

A Pre-Felling Treatment to

Prevent Sprouting of Red Maple

Dr. Rousseau succeeds Dr.

Harrison

Lockhart joins Dept. of

Trade and Commerce

University of Toronto Awards -..--

Tom Wright Becomes Dean

at U.B.C.

Yale Industrial Forestry Seminar

Reviews

Forest Products-Their Sources,

$22 \quad 7$

9

$\begin{array}{rrrrr}8 & 17 & 2 & 5 & \\ 13 & 13 & 4 & 3 & 3 \\ 14 & 12 & 3 & & 2\end{array}$

$8 i \quad 16 \quad 2 \quad 5$

Production and Utilization.

Current Publications.

Abstract of 1962 U.B.C.M.F. thesis.

Obituary

Canadian Theses in Forestry

and Related Subject Fields

Institute Affairs

1962 C.I.F. Gold Medal Winners.

General Activities of the

National Office.

News of the Sections.

Membership Changes.

$\begin{array}{llll}21 & 4 & 3 & 3 \\ 22 & 3 & 4 & 7\end{array}$


What in your opinion should be the prime purpose of the Forestry Chronicle?

To what type of news item should the Section News be limited?

General remarks.

(It is not necessary to identify yourself).

John P. Francis

${ }^{1}$ Editor's Note: As usual John Francis, News Representative of the Maritime Section, has made an important contribution to our knowledge about reader interest in the Chronicle. In reply to $\mathrm{my}$ request for information on these points he prepared, distributed, and analysed these questionnaires. The results of this study and the answers to the questions at the end which are too widely varying to summarize will be of value to myself and other members of our Editorial Board.

\section{QUEBEC}

A section meeting was held on December 7, 1962, in the Research Centre Building of Consolidated Paper Corporation Limited, at Grand'Mere.

Chairman E. T. Owens reviewed proceedings of the Annual Meeting in Vancouver, out of which developed a lengthy discussion on the need for additional facilities for publication in Canada of scientific articles in Forestry. There was good support for a Canadian Journal of Forest Science with several members challenging statements in the Editor's report. No decision was taken pending study of this report by the members.

A formal application for the division of the Section and formation of a new Section has been submitted by members of the Quebec City Area to C.I.F. President, L. Besley.

The Section stepped up its drive to increase its membership. Circulated to its 207 members were a list of the professional foresters resident in but presently not members of the Section and an exhortation to members to contact and encourage these foresters to join our Section.

J. M. CONWAY

\section{Algonquin}

An evening dinner meeting was held at the Northwood Hotel west of Pembroke on December 17, 1962. We were fortunate in having Consulting Forester, George Brown, of Ottawa as our guest speaker. His subject was the Island of Dominica, B.W.I., where he was lately in charge of a forest inventory prepared at the request of the government of that recently independent land. George went even beyond the realm of forestry, touching upon such subjects as history and politics, climate and geography, the people indigenous to the area and the economic aspects involved-particularly in connection with the establishment of a forest industry where none now exists. All in all he gave us a comprehensive picture of this small but interesting "Island in the Sun."

At 6.30 p.m. February 16, 1963, twenty five members and guests of the Algonquin Section gathered at the Petawawa Forest Experiment Station, Chalk River, Ontario. This was a dinner meeting followed by explanatory tours through the laboratories, and capped by a very informative talk on tree physiology by Dr. D. A. (Don) Fraser, of the Department of Forestry. It gave the non-research foresters and others a clearer idea of the need for 
basic research, the necessary building of pyramids of fact and data, contributory to any real scientific and technological advances in forestry.

DOUg TRUE

\section{OtTaWa Valley}

The 1962-63 executive of the Ottawa Valley Section is as follows: Chairman-Dr. A. S. Dyer, Vice Chairman-D. G. Yeomans, Councillors-G. B. Sully, J. C. Macleod, H. H. de Vries, D. J. Learmonth, W. E. McCraw, Secretary Treasurer-A. W. Blyth, Section Representative-V. J. Nordin.

The first meeting of the season, held on November 20, heard Dr. Harry Schwartz, Superintendent, Ottawa Laboratory, Forest Products Research Branch speak on the Commonwealth Forestry Conference, held during the past summer in Nairobi, Kenya. Dr. Schwartz, who was a member of the Canadian delegation to the conference, illustrated his talk with a series of colored slides covering the conference tour.

The second meeting of the Section, on January 15, was addressed by Mr. H. E. Seely, Chief, Forest Inventory Section, Forest Research Branch, on the subject " $70 \mathrm{~mm}$. Large-scale Photography as an Aid to Forest Inventory Work". The talk was illustrated with stereoscopic projections of photographs taken at scales of 200 and 100 feet to the inch in both colour and black and white. He emphasized how this photography has been used for detailed interpretation of forest conditions and for direct comparison with ground samples.

W. W. Calvert

\section{SOUTHERN ONTARIO}

The November meeting of the Section was addressed by Mr. D. D. Lockhart, Assistant Chief, Forest Products Section, Department of Trade and Commerce, Ottawa. His topic was "Problems of the softwood industry in North America"; this was the basis of recent discussions held between U.S. and Canadian representatives on Canadian lumber exports.

Mr. Lockhart explained the factors involved in the Pacific Northwestern states which initiated the talks, and dealt with points raised by the American lumbermen to support their claim of unfair Canadian competitive advantages. Such items as stumpage appraisals, manufacturing costs, and export of American logs to Japan had been effectively challenged. The devaluation of the Canadian dollar was an action supported and approved by the International Monetary Fund, and this body had obtained prior approval from the U.S. Government. Some proposals made by U.S. organizations to the United States Government for restricting the volume of Canadian lumber imports were also presented by the speaker.

Two items of particular interest were brought out by the speaker: (1) due to the Jones Act, regulating inter-coastal shipping, the proportionate volumes of lumber shipped from the Pacific States and B.C. to Atlantic ports changed considerably in a short time; in 1957, California, Oregon, and Washington shipped $78 \%$, B.C. $22 \%$-in 1961 , the corresponding percentages were $43 \%$ and $57 \%$. The Canadian advantage in using foreign vessels was $\$ 7$ to $\$ 11$ 
per Mf.b.m. (2) Of the total volume of lumber exported from B.C. in 1961, $76 \%$ went to the United States.

It was Mr. Lockhart's opinion that Canadian representatives had made good use of United States information to counter American proposals while, at the same time, proving that many of the problems of the American lumber industry were common to the domestic industry.

In December, Mr. J. W. Keenan, Timber Supervisor, Ontario Department of Lands and Forests, Tweed District, spoke on "Managing forests for timber and deer in the Tweed Forest District".

Dr. D. A. Wilson, Forest Economics Division, Department of Forestry, Ottawa, was the speaker at the January meeting. The title of his talk was "Supply and demand projections for forest products for western Europe and North America".

Because projected and actual supplies for the period under review showed significant differences, it is necessary, in studies of this kind, to consider more fully the impact of prices on the estimates. It was concluded that in order for Canada to play a significant role in international and internal economic planning committees, accurate statistics are required for the economically available forest products.

F. BUCKINGHAM

\section{Central Ontario}

Despite our interest in multiple uses of land, we in Central Ontario continue to be primarily concerned with the growing and greater utilization of wood. In this connection, the Abitibi Pulp and Paper Company will soon be doubling the capacity of their Abitibi Hard Board plant at Sturgeon Falls. Similarly, Milne's new mill, opened at Temagami last July, is capable of at least a 25 per cent increase in utilization of softwoods. A poplar plywood plant at Chapleau is another example of recently developed wood-using plants in our region, and the new sawmill of the Guelph Plywood Company at Mattawa, replacing the mill that burned in 1960, has a capacity of 2 million FBM of hardwood. Although demand for some wood products has been down in the Gogama District, the total production of the two principal industries in that district held steady at about 12 million FBM in 1962. An increasing demand for white birch short veneer bolts, especially in the Sudbury District, is helping to compensate for a somewhat lower demand for mine timbers. Progress toward eliminating wood waste is also apparent. Most saw mills producing over 3 million FBM per year in the region embraced by the Central Section now have barkers and chippers for processing waste.

Recreation is among our most rapidly growing uses of forest lands, and our more westerly districts are anticipating up to 25 per cent increases in the number of tourists next year. At least part of this increase will perhaps be due to the convenience of the new Sault Ste. Marie bridge that was opened late last fall. Campers this year will find new facilities at Massey, in the Sudbury District, and at Five Mile Lake and Sand Shoals' Lake, in the Chapleau District. Most of the other districts have camping facilities to meet the estimated influx of tourists, but a few of the existing camp sites will be enlarged. 
What impact will increasing numbers of tourists have on fishing in our Section of Ontario? Our fish biologists are more concerned with the carrying capacity of waters than with angling pressure. By rule-of-thumb, forest managers like to maintain a trout population of three or four pounds per acre. As an aid to meeting the carrying capacity of our northern waters, trout stocking (all species) by forest districts in 1962 were: Sault Ste. Marie, 500,000; Sudbury, 200,000; North Bay, 120,000; Chapleau, 28,000; and Gogama, 50,000. This level of stocking will be sustained, and possibly increased, in some areas this year. Tests for improving pickerel fishing in the Chapleau District were carried out last year by planting two lakes with parent stock netted from the Chapleau River. Similar tests will be made this year.

Multiple use of forest lands in meaningless without adequate protection of resources. Fire control was very successful in 1962, with five forest districts reporting numbers of fires and acreages burned as follows: Sault Ste. Marie -80 and 384; Gogama-44 and 224; Sudbury 322 and 4,381; North Bay (including Temagami)-141 and 1,258; and Chapleau-23 and 26. This satisfactory record can largely be attributed to early detection and suppression, and an experiment was conducted last fall near Thessalon to see if even earlier and more effective methods of detection are possible. The experiment was carried out by the Research Branch of the Ontario Department of Lands and Forests, with the De Haviland Aircraft Company and the Department of National Defence collaborating. The testing consisted of a series of flights over a designated area on which small fires, burning briquets on pans, had been set. Equipment in the aircraft monitored radiation from the fires and surrounding materials. The monitoring device, consisting of an optical system focussed on a cell sensitive to infra-red radiation, was coupled with electronic amplifiers. The Research Branch has not reported on the success of this operation.

Contributors to the above news items include: J. E. Gracie, G. A. Hamilton, J. Lockwood, G. A. McCormack, D. M. Peacock, D. C. Skeates, and W. C. Stevens.

W. A. REEKS

Northwestern Ontario

Our Annual Fall Social was held at Club Seaway, Fort William on November 30. Our members together with their wives and friends enjoyed an evening of dinner, dancing and sociabilities. Master of Ceremonies, George Breckenridge, supervised a number of stunts and draws and kept the evening moving right along. Incidentally, the profits from this function materially helped to defray our Section's commitments to the Lakehead College Forestry Library.

The regular January Section meeting missed January by one day, probably due to the cold weather, and was held February 1 at the West Fort Hotel. This proved to be one of the best attended meetings we have held in some time. Mr. Jim Mathieu of the Mathieu Lumber Company, Sapawe, discussed with us some of the major current problems and the economic status of the sawmill industry in Northwestern Ontario. This interesting and informative presentation will be remembered for some time. 
While not official C.I.F. Section projects, various members of this Section are presently considering or working on the following projects having a bearing on forestry matters:

The Enlarged Lakehead Conservation Authority.

Local Citizens' Arboretum Committee.

The establishment of a Forestry School in the expanding Lakehead College.

We are happy to report that our Chairman, M. R. McKay, was recently appointed General Logging Superintendent for the Great Lakes Paper Company.

R. S. HYSLOP

\section{LAKE OF THE WOODS}

On September 22, 1962, the thirteen members attending a meeting in Dryden were taken on a tour of the new Dryden Chemical Ltd. plant.

Mr. L. S. Paterson, Chairman, conducted a business meeting following the tour. The Ottawa Valley Section resolution concerning assistance to underdeveloped nations was read and a motion was made and carried "that the C.I.F. be asked to contact the Food and Agriculture Organization of the United Nations; they in turn to advise the C.I.F. whether opportunities exist for help from our organization; the C.I.F. in turn to determine whether foresters are interested."

Two new councillors, R. Balkwill and J. Breen, were elected to fill vacancies in our executive.

Nineteen members attended a meeting held in Kenora on November 17, 1962.

Chairman, L. S. Paterson, called on R.S.M. Bunney to report the highlights of the annual meeting.

W. G. Cleaveley and W. F. Beatty presented papers on scaling practices on a panel moderated by $R$. Boultbee. An interesting discussion followed.

W. F. BEATTY

\section{Manitoba}

Three general meetings of the Manitoba Section were held in Winnipeg during the period under review. Two of these were largely social in nature, one being held in Labatt's "Trophy Room" and the other being a dinner meeting to honour a departing member, George Edmonds, who has accepted a new appointment in Calgary. In spite of the distractions, necessary Section business was transacted at both these meetings.

The third meeting started with a conducted tour through the Forest Entomology and Forest Research Laboratories of the Manitoba-Saskatchewan District Office, Department of Forestry. This was followed by a lecture on "The Implications to Canada of the Common Agricultural Policy of the European Economic Community." The speaker was Dr. S. Sinclair, Head, Department of Agricultural Economics at the University of Manitoba. Following his interesting talk, the speaker showed a series of excellent coloured slides taken recently in the countries of the E.C.M. 
The most important item of current Section business is that a topic has been selected for the annual full-day technical meeting of the Section. The topic is "Forest Legislation in Manitoba". The scheduled date is April 5, 1963, and a tentative program is now being prepared.

R. A. HaIg

\section{SASKATCHEWAN}

A joint meeting between Manitoba and Saskatchewan sections was held on September 21st and 22nd at Dauphin, Manitoba. There was a business meeting, several field trips and a banquet. Everyone enjoyed themselves.

We have three new foresters in Prince Albert. Tom Buell, who comes from Nipigon, is the new manager of the Hardply Corporation in Prince Albert. Joe Jozsa, who hails from Hungary, has joined the Prince Albert Region of the Department of Natural Resources, and Bill Fairless, who comes from Banff, Alberta, has taken a position with the Inventory Division of the Department of Natural Resources Forestry Branch.

At the section meeting held on November 16th, 1962, ways were discussed of making meetings more interesting. Suggestions put forward were that papers be presented on topics other than forestry, as well as on forestry matters. It was also suggested that a model forest be set up by the section.

At the section meeting held on January 18th, 1963, an interesting talk was given by Mr. C. A. Ashfield, Public Relations Officer of the Industrial Information Office on "Industry in Saskatchewan."

D. R. CUTLer

\section{ROCKY MOUNTAIN}

The Rocky Mountain Section held its winter meeting on February 15 and 16 in Edmonton.

A business session was followed by a cocktail hour and a banquet on the first day of the meeting.

Dr. G. K. Goundrey, Associate Professor of Economics at the University of Alberta in Edmonton was guest speaker. The theme of Dr. Goundrey's talk was "The Role of Management in Canada's future pulp and paper industry." Lack of foresight and flexibility were in Dr. Goundrey's opinion among the major causes for the generally poor condition of Canada's pulp and paper industry. Management policies reflect, in many cases, the conditions of input and output existing at the time of the establishment of the industry. Since planning is usually 5 to 19 years ahead of production, production fails to satisfy immediate changes in demand. Dr. Goundrey stated his preference for management based on financial rotation to one based on physical rotation, and for intensive management rather than extensive management. A lively discussion followed Dr. Goundrey's stimulating talk.

The theme of a panel discussion on the second day of the meeting was "Management Policies of Wilderness Areas." Members on the panel were: Dr. W. A. Fuller, University of Alberta, representing the wildlife biologist's viewpoint, Mr. R. Loomis, Alberta Department of Lands and Forests, Mr. S. Kun, National Parks, and Mr. S. Burril, guide and outfitter. The panel members 
generally agreed that the "Wilderness Area" concept is inadequate for purposes of management, and that there is a need for creating "special-purpose areas", in order to minimize conflicting activities within the same area. The audience was well informed on the subject of "wilderness" thanks to an outline received two weeks prior to the winter meeting, and responded with well formulated opinions and questions.

The Section welcomes A. D. Kiil (T60) and C. L. Kirby (BC50), who have recently been transferred from the east to take positions with the Department of Forestry in Calgary. R. W. Pearson (BC62) and M. Sauze (BC61) have accepted positions with the Alberta Department of Lands and Forests in Edmonton and Slave Lake.

G. D. Paul (Mont57) has left Alberta and is presently enrolled in the Faculty of Education at California State College, San Diego, California. H. $\mathrm{K}$. Williams (BC51) has accepted a position with Western Plywood Ltd. at Quesnel. We wish these men success in their new careers.

Gus Loman

\section{KOOTENAY}

The December meeting of the Kootenay Section was devoted to questions, answers and discussion on recently implemented Forest Service policy with respect to sales of timber. Particular attention was paid to Pulpwood Harvesting Licenses and cut regulation in Sustained Yield Units. Many points of confusion were cleared up and the Forest Service officials concerned are to be congratulated on the effort and research which went into their presentations. Until this meeting it had appeared that Forest Service officials were just as confused as the operators over some of the recent introductions into policy. All parties must have benefited greatly from this clarification.

The Kootenay Section is planning to affirm its faith in the future of our forests and in planting as a forester's tool by establishing a small C.I.F. plantation in the neighbourhood of Nelson. Section members will form the planting crew and the plants have been raised in a Forest Service nursery from seeds collected by the forestry staff of a local sawmill. Planting will be carried out in the spring of 1963 and it is hoped that an expanded program may be developed to involve progressively more acreage and to include effective demonstrations of intensive forestry. It is hoped that other Sections will adopt this idea so that tree-planting and intensive forestry can be kept in the public eye, resulting, perhaps, in a public demand for more effective reforestation programs.

MiKe StEWART

\section{OKanagan}

An executive meeting was held on September 7, 1962 to outline the tentative program for the year. It was decided there would be three pre-Christmas functions. 
The schedule was carried out as planned.

Twenty members and guests attended a supper meeting on Sept. 28, at the Village Hotel banquet room in North Kamloops. Guest speakers were Mr. G. B. Boulton, consulting forester, and Mr. Al. Jessop, Western manager for the Farano Machinery Co.

The first speaker outlined a few of the anticipated problems in connection with the proposed pulp-sawmill economy in the Kamloops Area. Mr. Jessop spoke on barking and chipping and presented comparable facts and figures on different types of equipment used in this field.

A committee was appointed to study the problems pertaining to the proposed pulp-sawmill economy.

On November 2, 1962, thirty-two members and guests attended a joint C.I.F.-Vernon Hoo Hoo Club supper meeting held at the National Hotel banquet room in Vernon.

Two guest speakers were in attendance and the first to give his presentation was Mr. E. W. Smith, Sales Representative for Pacific Overland Timber Ltd., a lumber wholesale firm. Mr. Smith spoke on lumber marketing and briefly touched on the various fields. The second speaker was $\mathrm{Mr}$. A. H. Balison, General Manager for Balco Forest Products Ltd., a local lumbering firm. Mr. Balison was one of a group of business men selected to represent Canadian Forest Industries in a visit to study the United Kingdom and European Markets. He focused his talk on his observations made while on this tour.

The C.I.F., Okanagan Section held its monthly meeting in Falkland, November 23, 1962. They had as their guests members of the Interior Christmas Tree Producers Association and various Christmas Tree Handlers.

The meeting commenced with a field trip in the afternoon to visit various phases of the Christmas Tree Industry. This was followed by a supper meeting. Several specialists on Christmas Trees spoke on the subject. Mr. V. Hopkins, with the B.C. Forest Service in Lumby presented his discussion under two headings:

(1) the history of the industry in North America and

(2) management with a view to production and marketing of trees of better quality.

Other speakers were: Mr. H. R. Gavin, a forester for the B.C. Forest Service in Kamloops; Mr. Brock Hansen, a forester for Pondosa Pine Lumber Co. Ltd., Monte Lake; and Mr. Bob Kershaw, local manager for M. Walter \& Co.

S. NeIL McLean

\section{VANCOUVER}

Fifty members and guests attended our meeting on November 27 to conduct a minimum amount of business, hear reports, and enjoy an interesting program. 
Annual Meeting Chairman Bill McGhee presented a brief financial statement of our successful October event. Jim Collins, our C.I.F. Director, reported on the National Directors' meeting on the Sunday before the start of the annual meeting. One of our recently joined members, Miles Gibson, former Dean of the Faculty of Forestry at the University of New Brunswick, was made a C.I.F. Honorary Member at the Directors' meeting. Nomination of Dr. Gibson was by both the Maritimes Section and the Vancouver Section.

Tom Burgess, Vice-President of B.C. Forest Products Ltd. and current B.C. Lumber Manufacturers' Association President, gave an interesting coloredslide talk about his tour of forest operations and wood-products plants of European Russia last August. Mr. Burgess represented the B.C.L.M.A. on the tour, which was sponsored by a United Nations committee. The trip took him over 4,500 miles in the U.S.S.R.

Most interesting features of the illustrated talk were the strange machines developed for handling logs, since the start of Russian woods mechanization in 1947. The large proportion of women workers in the forest industry was startling.

Forty-five members and guests turned out January 15 to enjoy a meeting on modern forestry education, at the different levels now being offered or proposed in B.C. Two of the participating guests were E. C. Roper, head of the up-coming B.C. Institute of Technology, which will offer a subprofessional forestry curriculum and William Hall, Registrar of the B.C. Association of Professional Engineers.

Feature of the program was a panel moderated by member Charles Dunham, which included Eric Robinson, head of the B.C. Forest Service Ranger School, North Surrey, B.C.; Dr. B. G. Griffith, University of B.C. Faculty of Forestry; W. G. Burch, B.C. Forest Products Ltd.; Dave Bakewell, C. D. Schultz and Co. Ltd. The men covered technician education, professional education, education for industrial forestry and education for forestry consulting, respectively.

The panel was a signal event for Dr. Griffith. He presented a history of curriculum changes at the Faculty of Forestry. This was his first time as a guest speaker at a Vancouver Section meeting.

Gerry Burch told the meeting of the forestry crews which have been organized by three B.C. forest companies, as examples of good places for men with a technician-level education.

Miles Gibson from the floor, told the meeting of a survey in the Maritimes, in which it was found that professional foresters and forest technicians complement each other, on the basis of about 600 men in each class covered by the survey.

Someone pointed out that men, rather than trees, offer the greatest problems to foresters and forest sub-professionals alike. The intangible art of handling people can be acquired at any level of forestry education, it was the consensus. 
The fourth section meeting of the winter season brought out 45 members and guests for a program exploring a minor part of B.C.'s forest economy-the hardwoods of the province. The four hardwoods considered are red alder, western birch, northern black cottonwood and bigleaf maple. Peak year of hardwood cut in B.C. was 1945, when the cut of the four species amounted to one percent of the total provincial cut.

Dr. R. W. Wellwood, U.B.C. Faculty of Forestry, set the stage for the evening by stating pertinent points about the local utilization of hardwoods. He also acted as moderator for an interesting panel of five speakers.

Gerard Blom, of West Tree Farms Ltd., showed color slides and described islands in the lower Fraser River which have been, since 1956, developed for the growing mostly of hybrid poplars. Member firms in West Tree Farms are Western Plywood Ltd. and Westminster Paper Co. Ltd.

Dr. Phil Haddock gave the meeting a run-down on the silviculture of red alder. Sven Rasmussen, forester of the Tahsis Co. Ltd., informed the meeting of a program begun on the company tree farm on Vancouver Island for the establishment of firebreaks planted to exotic hardwoods. Similar firebreaks, 300 feet wide, Sven said, are being planted in northern Europe. The meeting could think of only the less inflammable foliage of hardwood as a reason for this.

Larry Milligan, of Vancouver's West Coast Hardwood Ltd., and Joe C. Robinson, of Simpson-Lee Paper Co., Everett, Washington, gave the C.I.F. men many interesting points about hardwood utilization in the Northwest on either side of the international boundary.

Meeting guests Dr. Donald Clark, Secretary-Manager of the Northwest Hardwoods Association, and Dr. Ben S. Bryant, Director of the University of Washington Institute of Forest Products, gave the meeting many other points of interest in the marketing of local hardwoods.

Points brought out by the two Washington visitors are that more and more red alder is being pulped by U.S. Northwest pulp-and-paper mills; the market for furniture stock is now the largest for Pacific Coast hardwoods.

ROBERT H. FORBES

\section{VANCOUVER ISLAND}

A general meeting was held at the Tzouhalem Hotel in Duncan on Nov. 30. About 50 members and wives enjoyed cocktails and dinner, followed by a business meeting and a slide illustrated talk.

Members were informed that Mr. Lorne Swannell had agreed to act as Liaison Officer between the Canadian Forestry Association and various Junior Forest Warden groups on Vancouver Island.

Chairman Ray Lejeune outlined the functions of the proposed B.C. C.I.F. Council and indicated that other B.C. Sections supported formation of this group. 
Our guest speaker was Mr. Gerry McKee, Deputy Minister of Forests, who showed a selection of excellent color slides taken in Africa during his attendance at the 1962 British Commonwealth Forestry Conference. Mr. McKee's slides and narrative covered many of the forestry, social and political problems that exist in Africa today.

A January dance was held at the Crystal Gardens in Victoria and was enjoyed by approximately 60 members, wives and guests. Invited as guests of the Section in appreciation of their work with the Junior Forest Wardens association were Mr. and Mrs. Robinson, Mr. and Mrs. Glover, Mr. and Mrs. Dawes, Mr. Ken Mitchell, Mr. W. F. Myring and Mr. W. Moire.

R. O. MACMillen

For your convenience The Forestry Chronicle offers a free employment service. Prospective employers or applicants should write to Mr. George A. Sinclair, Ontario Department of Lands \& Forests, Tweed, Ontario, who will prepare applications for publication. Applicants are requested to include their own advertisement giving the following information: University granting degree, year of graduation, years and type of experience and type of employment preferred.

\title{
Employment Wanted
}

Young forestry engineer, graduated from the Swiss Federal Institute of Technology in 1956, seeks employment in forestry or forest engineering. Five years of experience in road location and development planning in British Columbia, also some experience in road construction and maintenance. Please refer to Code No. F.E.1.

\section{Attractive New Sets of First Issues of}

\section{The FORESTRY CHRONICLE}

\author{
$\$ 8.00$ bound by Year (or 4 issues)
}

or

$\$ 60.00$ for the Set of 1925 to 1932

Write to

C.I.F.

c/o Macdonald College P.O.

Macdonald College, P.Q. 